\title{
UČITELJSKA PROCJENA ZNANJA O SIMPTOMIMA, ETIOLOGIJI I TRETMANU ADHD-A
}

\author{
Sanja Skočić Mihić ${ }^{1}$, Snježana Sekušak Galešev ${ }^{2}$, \\ Selma Kehonjićc ${ }^{3}$ \\ ${ }^{1}$ Učiteljski fakultet, Sveučilište u Rijeci, Hrvatska \\ ${ }^{2}$ Edukacijsko-rehabilitacijski fakultet, Sveučilište u Zagrebu, \\ Hrvatska \\ ${ }^{3}$ Osnovna škola »Ivo Lola Ribar«, Labin, Hrvatska \\ sskocic_m@uniri.hr; snjezana.sekusak-galesev@erf.unizg.hr
}

Primljeno: 25. 3. 2021.

Cilj je studije bio utvrditi učiteljsku procjenu znanja o simptomima, etiologiji itretmanu ADHD-a te njenu povezanost sa sociodemografskim obilježjima učitelja, obilježjima škole i učiteljevoj samoprocjeni općeg znanja o ADHD-u. Prigodan uzorak činilo je 233 učitelja. Primijenjen je Upitnik učiteljskih znanja o ADHD-u trofaktorske strukture: Simptomi, Etiologija i Tretman ADHD-a, odgovarajuće pouzdanosti. Učitelji poznaju važnost tretmana za akademske i socijalne ishode učenika s ADHD-om te simptome ADHD-a, dok iskazuju nedovoljno poznavanje etiologije ADHD-a. Prisutne su zablude u identificiranju uzroka ADHD-a u obiteljskim stresnim okolnostima. Učiteljska procjena općeg znanja o ADHD-u povezana je s višom razinom znanja o simptomima i tretmanu, radnim mjestom učitelja razredne nastave, dok je viša razina znanja o tretmanu povezana s nižom kronološkom dobi učitelja. Implikacije dobivenih nalaza ukazuju na značaj stjecanja kompetencija učitelja za poučavanje učenika s ADHD-om tijekom inicijalnog obrazovanja i trajnog profesionalnog razvoja, kao i osiguravanja podrške stručnjaka edukacijskih rehabilitatora.

Ključne riječi: znanja, učitelji, ADHD, simptomi, etiologija, tretman

\section{Uvod}

Deficit pažnje/hiperaktivni poremećaj (ADHD) čest je neurorazvojni poremećaj u djetinjstvu sa značajnim implikacijama na djeteto- 
vo akademsko, socijalno i emocionalno funkcioniranje (npr. American Psychiatric Association, 2013; Barkley, 1997; Rader et al., 2009; Blotnicky-Gallant et al., 2014; Azazy et al., 2018). Prema DSM-5 razlikuju se dvije dijagnostičke kategorije: (1) nepažnja i (2) hiperaktivnost/ impulzivnost (American Psychiatric Association, 2013). Dijagnostički protokol uključuje pojavnost »ustrajnog obrasca šest simptoma nepažnje/hiperaktivnost i impulzivnost« prije 12. godine života djeteta u »najmanje dvije socijalne sredine (obitelj, škola i druge)《 u trajanju najmanje šest mjeseci, koji su »nesrazmjerni razvojnom stupnju djeteta«, »utječu ili smanjuju kvalitetu socijalnog, akademskog i radnog funkcioniranja« i ne mogu se opisati drugim teškoćama mentalnog zdravlja (Reynolds i Kamphaus, 2013, 2-3).

Upravo ovisno o dijagnostičkim kriterijima i obuhvaćenoj populaciji, prevalencija ADHD-a kreće se od $2 \%$ do $18 \%$ (Rader et al., 2009, 657), uz veću pojavnost kliničkih simptoma kod dječaka $(4,5: 1)$, napose impulzivnosti i hiperaktivnosti (npr. Faraone et al., 1998; Jurin i Sekušak-Galešev, 2008).

Nadalje, etiologija je kompleksna, multifaktorska i interakcijska, a uključuje biološke i psihosocijalne čimbenike (npr. Russell et al., 2016). Dominiraju teorije o genetskim i organskim faktorima: (1) promjene moždanih struktura područja neuralne mreže predfrontalnog režnja, bazalnih ganglija i malog mozga, amigdale i drugih, odgovornih za inhibiciju izvršnih funkcija (Barkley, 2006; Felt et al., 2014; Vaidya, 2012), (2) snižene razine neurotransmitera dopamina i noradrenalina (npr. Rader et al., 2009) koja je posljedica »pretjerane ekspresije transportera u preuzimanju « ovih neurotransmitera na »presinaptičkim završetcima pa stoga dolazi do insuficijentne interakcije s postsinaptičkim receptorima i prebrzog recikliranja neurotransmitera « (Jurin i Sekušak, 2008, 196). Okolinski činitelji promatraju se u kontekstu interakcije genetskih/bioloških predispozicija i okolinskih činitelja (Russell et al., 2016). Okolinski čimbenici, odnosno nepovoljni odgojni utjecaji, disfunkcionalni odnosi, neprimjerena prehrana bogata šećerima i aditivima te prekomjerno izlaganje televizijskim i drugim ekranima nisu etiološki čimbenici premda utječu na jačinu simptoma ADHD-a (Jurin i Sekušak-Galešev, 2008). Simptomi teškoća pažnje, impulzivnosti i hiperaktivnosti vidljivi su u nižoj razini kontrole ponašanja djeteta $u$ društvenim interakcijama i samoregulaciji, što utječe na ograničenja u 
interakcijama s vršnjacima i odraslim osobama te cjelokupno funkcioniranje djeteta u obitelji i zajednici. Simptomi neizostavno utječu na školska postignuća, koncentraciju i samokontrolu (Al-Moghamsi et al., 2018), a strukturirani zahtjevi u školskom okruženju dovode do akademskih i socijalnih teškoća, teškoća učenja, smanjenih školskih postignuća i emocionalnih teškoća popraćenih anksioznošću i depresijom (npr. Sekušak-Galešev, 2004). Prisutne su teškoće u izvršavanju funkcija, slijeđenju uputa, usmjeravanju, održavanju i dugotrajnom zadržavanju pažnje na zadatku, zaboravljanju u izvršavanju zadataka, organiziranju i planiranju, samokontroli, ometanju, prisutnom motoričkom nemiru... (npr. Rader et al., 2009; Barkley, 2015; Alkahtani, 2013; Opić i Kudek Mirošević, 2011; Jurin i Sekušak-Galešev, 2008; Sekušak-Galešev et al., 2015).

U tretmanu ADHD-a koriste se različiti pristupi koji se kombiniraju iz skupine farmakoterapije i psihosocijalnih pristupa koji su usmjereni na modeliranje ponašanja i socijalnih vještina učenika s ADHD-om (npr. Jurin i Sekušak-Galešev, 2008). Iako se većina spoznaja o ovom neurorazvojnom poremećaju temelji na kliničkim studijama (Rowland et al., 2015), tretman je usmjeren na kombinaciju bihevioralnih intervencija, osobito za predškolsku djecu, među kojima su osobito učinkovite one koje nagrađuju pozitivno ponašanje, educiranje roditelja, strategije upravljanja razredom, vršnjačke intervencije i psihofarmakološke intervencije, uglavnom za stariju djecu (Felt et al., 2014; Rader et al., 2009).

Tretman uključuje pozitivna potkrepljenja (npr. nagrade, privilegije i slično), negativna potkrepljenja (uskrata privilegija), planirano ignoriranje, strukturirano, sigurno i predvidljivo razredno okruženje, »vidljivost « prostora bez pregrada, područja za aktivnosti i odmor, kontrolu poticaja i buke, emocionalnu podršku, prilagodbe u poučavanju (osiguravanje dodatnog vremena za zadatak, dijeljenje zadatka u manje korake), dosljednu primjenu dogovorenih pravila itd. (Kos et al., 2006). Najbolje učinke ima multimodalni pristup radi koordinirane suradnje profesionalaca različitih struka i roditelja u osiguravanju strukturiranih uvjeta i pozitivnoga utjecaja na akademski i socio-emocionalni razvoj djeteta s ADHD-om (npr. Jurin i Sekušak-Galešev, 2008; Atkinson i Shute, 1999). Barkley (2015) ističe značaj podrške roditeljima djeteta 
s ADHD-om i smjernica u olakšavanju izazovnih situacija u odgajanju djeteta s ADHD-om.

Učenici s ADHD-om koji se upućuju u dijagnostički postupak najčešće su identificirani od strane učitelja ili roditelja radi akademskih i socio-emocionalnih teškoća u strukturiranim situacijama u razredima (npr. Snider et al., 2003; Wolraich et al., 2003; Vlah et al., 2018). Očekuje se da su učitelji »osposobljeni prepoznati osnovne simptome ADHD-a« (Soroa et al., 2014, 1035), da sudjeluju u procesu dijagnoze, primjeni i evaluaciji multimodalnih pristupa u tretmanu (Vlah et al., 2018).

Učitelji nedovoljno poznaju značajke učenika s ADHD-om, nedostatno su osposobljeni za poučavanje ovih učenika tijekom inicijalnog obrazovanja i trajnog profesionalnog razvoja, a znanja stječu kroz medije, razgovorom s prijateljima i rodbinom i samostalnim proučavanjem literature (npr. Blotnicky-Gallant et al., 2014; Brook et al., 2000; Al-Hakeem et al., 2013; Kos et al., 2006; Kos et al., 2004; Ghanizadeh et al., 2006; Snider et al., 2003). Također, imaju više znanja o simptomima ADHD-a, a manje o uzrocima, ishodima i tretmanu (npr. Abed et al., 2014; Soroa et al., 2014; Vereb i DiPerna, 2004).

Radetić-Paić (2018) ukazuje na nedostatnu razinu znanja hrvatskih učitelja za poučavanje učenika s ADHD-om, a koliko je autorima poznato nije provedeno istraživanje o znanjima učitelja o učenicima s ADHD-om validiranim mjernim instrumentom. Stoga je cilj ovoga rada utvrditi: (1) samoprocijenjenu razinu znanja učitelja o učenicima s ADHD-om; (2) utvrditi postoji li povezanost između samoprocijenjene razine znanja učitelja o učenicima s ADHD-om sa sociodemografskim obilježjima učitelja (dob, godine radnog staža, razina obrazovanja: preddiplomska i diplomska razina) i obilježjima škole (veličina, radno mjesto: predmetna /razredna nastava) te (3) s njihovom procjenom razine općenitog znanja o ADHD-u (»Kako biste, na ljestvici od 0 do 10, opisali svoje znanje o ADHD-u: $0=$ nikakvo, $10=$ izvrsno $)$.

Sukladno ciljevima postavljene su hipoteze istraživanja:

H.1. Znanja učitelja o učenicima s ADHD-om niža su u dimenziji etiologije ADHD, a viša u dimenzijama simptoma i tretmana ADHD-a.

H.2. Postoji statistički značajna povezanost između sve tri dimenzije znanja te njihova povezanost sa sociodemografskim čimbenicima 
(kronološkom dobi, godinama radnog staža, razinom obrazovanja, radnim mjestom u razrednoj nastavi i radom u matičnoj ili područnoj školi) te samoprocijenjenoj razini općeg znanja.

\section{Metoda}

\subsection{Uzorak}

U istraživanju je sudjelovalo 233 učitelja razredne i predmetne nastave $(\check{Z}=93 \%, M=7 \%)$ zaposlenih u osnovnoškolskim ustanovama iz Istarske, Primorsko-goranske i Karlovačke županije. Prosječna dob učitelja je 43 godine $(\mathrm{SD}=9,80 ; \mathrm{Min}=23$; Max=64) s prosječno 17 godina radnog staža $(\mathrm{SD}=10,53 ; \mathrm{Min}=0 ; \mathrm{Max}=40)$.

Gotovo polovina (45 \%) učitelja završila je četverogodišnji sveučilišni studij, $26 \%$ dvogodišnji stručni studij, $15 \%$ četverogodišnji stručni studij, a $14 \%$ petogodišnji sveučilišni studij. Okvirno polovica uzorka (54 \%) su učitelji predmetne, a $46 \%$ razredne nastave, koji su većinom ( $85 \%$ ) zaposleni u matičnoj školi. U školama koje pohađa manje od 150 učenika poučava $13 \%$ učitelja, u školama koje pohađa od 151 do 499 učenika poučava $79 \%$ učitelja, a u školama koje pohađa više od 500 učenika poučava $8 \%$ učitelja.

\subsection{Mjerni instrument}

Nezavisne varijable istraživanja odnosile su se na sociodemografska obilježja učitelja (dob, godine radnog staža, razina završenog studija: dvogodišnji stručni studij/četverogodišnji stručni studij/četverogodišnji sveučilišni studij/petogodišnji, radno mjesto: predmetna i razredna nastava) te obilježja škole: veličina (mala, srednja i velika) i ustrojstvo (matična i područna škola).

Samoprocjena znanja o ADHD-u mjerila se unisonom varijablom »Kako biste, na ljestvici od 0 do 10, opisali svoje znanje o ADHD-u?« i predstavlja učiteljsku procjenu razine općeg znanja o ADHD-u na od 'nikakvo' do 'izvrsno' znanje.

Upitnik učiteljskog znanja ADHD-a (Questionnaire to Assess Teachers Knowledge of ADHD; Soroa et al., 2014), preuzet uz dozvolu autora, izvorno sadrži 26 čestica koje ispituju znanja učitelja o etiolo- 
giji ADHD-a (4 čestice), simptomima (11 čestica), opće informacije (4 čestice) i tretmanu (7 čestica). Stupanj slaganja s tvrdnjama upitnika učitelji su procjenjivali na upitniku Likertovog tipa od 5 stupnjeva (od $1=$ uopće ne, do $5=u$ potpunosti se slažem).

Faktorskom analizom utvrđena je latentna struktura upitnika na uzorku hrvatskih učitelja sadrži tri faktora s 22 čestice. Čestice faktora općih informacija o ADHD-u iz originalnog istraživanja (Postotak dječaka i djevojčica s ADHD-om jest podjednak; Dječaci s ADHD-om češće imaju veći stupanj hiperaktivnosti-impulzivnosti nego djevojčice; Mladi ljudi s ADHD-om odustaju od škole češće nego drugi; Općenito, pretjerane aktivnosti smanjuju se $u$ adolescenciji, iako impulzivnost $i$ teškoće pažnje ostaju) nisu zadržale pripadnost faktoru, imale su niske komunalitete i izostavljene su iz obrade. Zasićenje čestica, svojstvene vrijednosti, postotak zajedničke varijance i pouzdanost faktora prikazani su u Tablici 1.

Tablica 1. Faktorska struktura Upitnika znanja učitelja o učenicima s ADHD-om

\begin{tabular}{|c|c|c|c|}
\hline Faktori & 1 & 2 & 3 \\
\hline \multicolumn{4}{|l|}{ Simptomi ADHD-a } \\
\hline \multicolumn{4}{|l|}{ Djeca s ADHD-om ... } \\
\hline $\begin{array}{l}\text {... ponašaju se bez razmišljanja o posljedi- } \\
\text { cama njihovih djela. }\end{array}$ & ,746 & & \\
\hline $\begin{array}{l}\text {.. imaju poteškoća u uvažavanju razred- } \\
\text { nih pravila i društvenih normi. }\end{array}$ & ,693 & & \\
\hline $\begin{array}{l}\text {... počinju odgovarati prije nego njihov } \\
\text { sugovornik završi s postavljanjem } \\
\text { pitanja. }\end{array}$ & ,659 & & \\
\hline $\begin{array}{l}\text {... često gube stvari poput odjeće, škol- } \\
\text { skog pribora, igračaka itd. }\end{array}$ & ,652 & & \\
\hline $\begin{array}{l}\text {... se žale kada trebaju izvoditi zadatke u } \\
\text { kojima trebaju održati mentalni napor i } \\
\text { pokušavaju ih izbjeći. }\end{array}$ & ,645 & & \\
\hline $\begin{array}{l}\text {... prekidaju ili upadaju u aktivnosti } \\
\text { drugih. }\end{array}$ & ,612 & & \\
\hline
\end{tabular}


... imaju poteškoća dok čekaju svoj red. , ,603

... često su sklona zaboravljanju stvari. , ,595

... izgledaju kao da ne slušaju dok im se govori.

... često imaju poteškoća u kontroliranju njihovih emocija, posebice ljutnje.

... imaju poteškoća u završavanju zadataka koje su započeli.

\section{Etiologija ADHD-a}

ADHD može biti uzrokovan lošim obrazovanjem ili kaotičnim obiteljskim okruženjem.

Stresni događaji poput razvoda roditelja ili rođenje novog brata ili sestre mogu uzrokovati ADHD.

Kod djece, ADHD može biti uzrokovan stresom izazvanim trenutnim tempom života.

Kritički i autoritaran odgojni stil roditelja može voditi do ADHD-a.

\section{Tretman ADHD-a}

Uspješnost u nastavi i prilagodba na školu djece s ADHD-om mogu se poboljšati ako se učitelj stručno usavršava za poučavanje ovih učenika.

Informiranje o ADHD-u poboljšava stavove učitelja, roditelja i učenika iz razreda o djeci s ADHD-om.

Suradnja učitelja u tretmanu djeteta $\mathrm{s}$ ADHD-om ima utjecaja na rezultate liječenja.

Postoje specifične tehnike i programi za poboljšanje raspona pažnje djece s ADHDom.

Roditelji i učitelji djece s ADHD-om trebaju aktivno sudjelovati u primjeni psiholoških postupaka. 
Čekajući da se simptomi ADHD-a poboljšaju s godinama, bez ikakvog tretmana, znači oduzimanje mogućnosti za budućnost djeteta.

Učitelj mora pružiti prilike učenicima s ADHD-om da kanaliziraju svoje pretjerano kretanje.

\begin{tabular}{llll}
\hline Svojstvene vrijednosti & 6,24 & 2,34 & 1,81 \\
\hline Postotak zajedničke varijance $\%$ & $28,36 \%$ & $10,64 \%$ & $8,25 \%$ \\
\hline Cronbach alfa koeficijent & 0,86 & 0,70 & 0,80 \\
\hline
\end{tabular}

Ekstrahirana su tri faktora, postotak ukupno objašnjene varijance u odnosu na cjelokupan prostor manifestnih varijabli iznosi 47,27 \%, Bartlettov test je 0,84 , pouzdanost prvog i trećeg faktora je odgovarajuća, a drugog zadovoljavajuća (redom 0,86, 0,70, 0,80). Zadržana je originalna struktura tri faktora i naziva. Zadržan je originalni naziv faktora za 'Simptome', iako bi u odgojno-obrazovnom kontekstu bilo primjerenije imenovanje 'Obilježja ADHD-a'.

\subsection{Način provođenja istraživanja}

Istraživanje je odobreno od Učiteljskog fakulteta u Rijeci. Ravnateljima škola poslan je upit za sudjelovanjem u istraživanju i nakon njihovog odobrenja upitnici su distribuirani u škole. Učitelji su dobrovoljno i anonimno sudjelovali $u$ istraživanju, a cilj istraživanja i upute bile su navedene u upitniku. Dio prikupljenih rezultata korišten je u izradi diplomskog rada (Kehonjić, 2016).

\subsection{Metode obrade podataka}

Izračunati su osnovni statistički pokazatelji na svim česticama Upitnika (aritmetička sredina i standardna devijacija). Za utvrđivanje latentnog prostora provedena je faktorska analiza metodom glavnih komponenata, uz oblimin rotaciju, a za izlučivanje faktora korišten je Guttman-Kaiserov kriterij i scree plot. Izračunat je Cronbach alpha koeficijent s ciljem provjeravanja pouzdanosti. Testirana je normalnost distribucije rezultata Kolmogorov-Smirnov testom. Za utvrđivanje po- 
vezanosti među faktorima, kao i između faktora i sociodemografskih varijabli, korišten je Spearmanov koeficijent korelacije za kontinuirane varijable, a Kendall Tau test za dihotomne varijable.

\section{Rezultati i rasprava}

Osnovni deskriptivni pokazatelji na Upitniku znanja o ADHD-u prikazani su u Tablici 2.

Tablica 2. Osnovni statistički podaci na Upitniku znanja učitelja o ADHD-om

\begin{tabular}{|c|c|c|c|}
\hline & \\
\hline & $\mathrm{N}$ & $\begin{array}{l}\text { Min- } \\
\text { Max }\end{array}$ & $\mathrm{M}(\mathrm{SD})$ \\
\hline Simptomi ADHD-a & 211 & 2,64 & $4,06(0,52)$ \\
\hline \multicolumn{4}{|l|}{ Djeca s ADHD-om ... } \\
\hline $\begin{array}{l}\text {...često imaju poteškoća u kontroliranju } \\
\text { njihovih emocija, posebice ljutnje. }\end{array}$ & 225 & $1-5$ & $4,26(0,70)$ \\
\hline $\begin{array}{l}\text {.. počinju odgovarati prije nego njihov su- } \\
\text { govornik završi s postavljanjem pitanja. }\end{array}$ & 221 & $3-5$ & $4,25(0,69)$ \\
\hline $\begin{array}{l}\text {... imaju poteškoća u završavanju zadata- } \\
\text { ka koje su započeli. }\end{array}$ & 223 & $2-5$ & $4,24(0,70)$ \\
\hline ... imaju poteškoća dok čekaju svoj red. & 223 & $1-5$ & $4,19(0,73)$ \\
\hline $\begin{array}{l}\text {... imaju poteškoća u uvažavanju razred- } \\
\text { nih pravila i društvenih normi. }\end{array}$ & 225 & $2-5$ & $4,15(0,80)$ \\
\hline $\begin{array}{l}\text {... prekidaju ili upadaju u aktivnosti } \\
\text { drugih. }\end{array}$ & 223 & $1-5$ & $4,14(0,75)$ \\
\hline $\begin{array}{l}\text {... izgledaju kao da ne slušaju dok im se } \\
\text { govori. }\end{array}$ & 222 & $2-5$ & $4,14(0,72)$ \\
\hline $\begin{array}{l}\text {.. ponašaju se bez razmišljanja o poslje- } \\
\text { dicama njihovih djela. }\end{array}$ & 220 & $1-5$ & $3,97(0,87)$ \\
\hline $\begin{array}{l}\text {... se žale kada trebaju izvoditi zadatke u } \\
\text { kojima trebaju održati mentalni napor i } \\
\text { pokušavaju ih izbjeći. }\end{array}$ & 221 & $1-5$ & $3,90(0,92)$ \\
\hline ... često su sklona zaboravljanju stvari. & 221 & $1-5$ & $3,78(0,90)$ \\
\hline $\begin{array}{l}\text {... često gube stvari poput odjeće, škol- } \\
\text { skog pribora, igračaka itd. }\end{array}$ & 222 & $1-5$ & $3,64(0,98)$ \\
\hline
\end{tabular}




\begin{tabular}{|c|c|c|c|}
\hline Etiologija ADHD-a & 207 & 1,25 & $3,21(0,80))$ \\
\hline $\begin{array}{l}\text { Kritički i autoritaran odgojni stil roditelja } \\
\text { (ne) može voditi do ADHD-a_rec }\end{array}$ & 221 & $1-5$ & $3,48(1,1)$ \\
\hline $\begin{array}{l}\text { ADHD (ne) može biti uzrokovan lošim } \\
\text { obrazovanjem ili kaotičnim obiteljskim } \\
\text { okruženjem_rec }\end{array}$ & 216 & $1-5$ & $3,16(1,17)$ \\
\hline $\begin{array}{l}\text { Stresni događaji poput razvoda roditelja } \\
\text { ili rođenje novog brata ili sestre (ne) } \\
\text { mogu uzrokovati ADHD_rec }\end{array}$ & 215 & $1-5$ & $3,02(1,11)$ \\
\hline $\begin{array}{l}\text { Kod djece, ADHD (ne) može biti uzroko- } \\
\text { van stresom izazvanim trenutnim tempom } \\
\text { života_rec }\end{array}$ & 214 & $1-5$ & $2,98(1,11)$ \\
\hline Tretman ADHD-a & 207 & 2,86 & $4,27(0,50)$ \\
\hline $\begin{array}{l}\text { Roditelji i učitelji djece s ADHD-om } \\
\text { trebaju aktivno sudjelovati u primjeni } \\
\text { psiholoških postupaka. }\end{array}$ & 223 & $2-5$ & $4,53(0,63)$ \\
\hline $\begin{array}{l}\text { Informiranje o ADHD-u poboljšava } \\
\text { stavove učitelja, roditelja i učenika iz } \\
\text { razreda o djeci s ADHD-om. }\end{array}$ & 222 & $2-5$ & $4,47(0,70)$ \\
\hline $\begin{array}{l}\text { Uspješnost u nastavi i prilagodba na školu } \\
\text { djece s ADHD-om mogu se poboljšati } \\
\text { ako se učitelj stručno usavršava upravo za } \\
\text { ovu teškoću. }\end{array}$ & 223 & $2-5$ & $4,35(0,76)$ \\
\hline $\begin{array}{l}\text { Postoje specifične tehnike i programi } \\
\text { za poboljšanje raspona pažnje djece s } \\
\text { ADHD-om. }\end{array}$ & 220 & $2-5$ & $4,13(0,72)$ \\
\hline $\begin{array}{l}\text { Čekajući da se simptomi ADHD-a pobolj- } \\
\text { šaju s godinama, bez ikakvog tretmana, } \\
\text { znači oduzimanje mogućnosti za buduć- } \\
\text { nost djeteta. }\end{array}$ & 223 & $2-5$ & $4,10(0,82)$ \\
\hline $\begin{array}{l}\text { Suradnja učitelja u tretmanu učenika } \\
\text { s ADHD-om ima utjecaja na rezultate } \\
\text { tretmana. }\end{array}$ & 217 & $1-5$ & $4,06(0,76)$ \\
\hline $\begin{array}{l}\text { Učitelj mora pružiti prilike učenicima s } \\
\text { ADHD-om da kanaliziraju svoje pretjera- } \\
\text { no kretanje. }\end{array}$ & 220 & $2-5$ & $4,28(0,72)$ \\
\hline
\end{tabular}

Kazalo: $\mathrm{N}=$ ukupan broj; $\mathrm{Min}=$ minimalna vrijednost; $\mathrm{Max}=$ maksimalna vrijednost; $\mathrm{M}=$ aritmetička sredina; $\mathrm{SD}=$ standardna devijacija 
Kao što je iz Tablice 2 vidljivo, na svim česticama Upitnika dobiven je maksimalni rezultat. Minimalna vrijednost dobivena je na svim česticama Etiologije ADHD- $a$ i na sedam čestica Simptoma ADHD-a, što govori da su odgovori učitelja u najširem mogućem rasponu od potpunog neslaganja do potpunog slaganja. Najmanji varijabilitet $\mathrm{i}$ najviši rezultati slaganja učitelja s tvrdnjama su na česticama Tretman $A D H D-a$, i to u potpunosti se slažu da »roditelji i učitelji djece s ADHD-om trebaju aktivno sudjelovati u primjeni psiholoških postupaka« te gotovo da »informiranje o ADHD-u poboljšava stavove učitelja, roditelja i učenika iz razreda o djeci s ADHD-om«.

Najviša prosječna vrijednost je na Tretmanu ADHD-a $(\mathrm{M}=4,27)$, što ukazuje na to da učitelji najviše poznaju značaj dobrobiti tretmana $\mathrm{i}$ timske suradnje na pozitivne ishode učenika s ADHD-om.

Viša razina znanja učitelja prisutna je i u odnosu na poznavanje simptoma učenika s ADHD-om $(\mathrm{M}=4,06)$. Niže vrijednosti u odnosu na prethodna dva faktora dobivene su na Etiologiji ADHD-a $(\mathrm{M}=3,21)$ i ukazuju na osrednje slaganje učitelja o tome da su stresni čimbenici u obiteljskim okolnostima uzrok ADHD-a. Četiri čestice koje čine ovaj faktor rekodirane su i viši rezultat ukazuje na višu razinu zablude o etiologiji povezane s uvjerenjem da ADHD uzrokuje primjerice »stres izazvan trenutnim tempom života« ili »stresnim događajem poput razvoda roditelja ili rođenja novog brata ili sestre«.

Sukladno postavljenoj prvoj hipotezi, utvrđena je viša razina znanja učitelja o tretmanu i simptomima ADHD-a i niža razina znanja o etiologiji ADHD-a.

Provjerena je normalnost distribucije rezultata i normalna distribucija rezultata utvrđena je samo na faktoru Simptoma $\left(\right.$ redom $z_{1,2,3}=0,798$; $\left.1,664^{* * ;}, 1,745^{* *}\right)$. Stoga je za utvrđivanje povezanosti među faktorima, kao i povezanost faktora sa sociodemografskim varijablama izračunat Spearmanov koeficijent korelacije za kontinuirane nezavisne varijable (Tablica 3). 
Tablica 3. Interkorelacije među faktorima Upitnika znanja učitelja o $A D H D-u$ i korelacije faktora sa sociodemografskim varijablama i samoprocijenjenim znanjem

\begin{tabular}{|c|c|c|c|c|}
\hline & \multirow{2}{*}{ Simptomi } & \\
\hline & & & Etiologija $^{R}$ & Tretman \\
\hline \multirow{3}{*}{$\begin{array}{l}\bar{\Xi} \\
\frac{\vec{t}}{\pi} \\
\frac{\pi}{\pi}\end{array}$} & Simptomi & 1,000 &,- 131 &, $501 * * *$ \\
\hline & Etiologija $^{\mathbf{R}}$ & & 1,000 & ,004 \\
\hline & Tretman & & & 1,000 \\
\hline \multirow{4}{*}{ 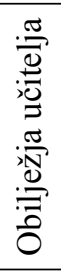 } & Dob &,- 103 &,- 098 &,$- 150 *$ \\
\hline & Radni staž &,- 099 &,- 091 &,- 132 \\
\hline & Razina obrazovanja &,- 036 &, 070 &, 085 \\
\hline & $\begin{array}{l}\text { Radno mjesto } \\
\left(\text { predmetna/razredna) }{ }^{\mathrm{K}}\right.\end{array}$ &, $\mathbf{1 6 0}^{* *}$ &, 067 &, 090 \\
\hline \multirow{3}{*}{$\frac{\frac{0}{0}}{\frac{0}{\omega n}}$} & Veličina škole &,- 079 & , 142 & , 102 \\
\hline & Škola (područna/matična) & 036 &,- 057 &, 094 \\
\hline & $\begin{array}{l}\text { Samoprocjena znanja } \\
\text { o ADHD-u }\end{array}$ &, $228^{* *}$ &, 047 &, $\mathbf{1 7 8}^{* *}$ \\
\hline
\end{tabular}

Legenda $: *=\mathrm{p}<0,05 ; * *=\mathrm{p}<0,01 ; * * *=\mathrm{p}<0,001 ; \mathrm{R}$-rekodirane čestice; ${ }^{\mathrm{K}}$-Kendel Tau analiza za dihotomne varijable

Na unisonoj varijabli procjene znanja o ADHD-u učitelji procjenjuju da imaju osrednju razinu znanja o ADHD-u $(\mathrm{N}=201 ; \mathrm{M}=4,81$; $\mathrm{SD}=1,865 ; \operatorname{Min}=0 ; \mathrm{Max}=10$ ).

Utvrđena je visoka statistički značajna povezanost između učiteljske procjene znanja o simptomima i tretmanu ADHD-a, niska razina povezanosti ove dvije dimenzije sa samoprocjenom općeg znanja učitelja o ADHD-u i niska negativna povezanost između tretmana i dobi učitelja. Učitelji koji procjenjuju višu razinu znanja o ADHD-u, procjenjuju da bolje poznaju tretman i da imaju višu razinu općeg znanja o ADHD-u, a mlađi učitelji iskazuju višu razinu znanja o tretmanu ADHD-a.

Nije utvrđena povezanost simptoma i tretmana s etiologijom ADHD-a, kao niti s radnim stažem, razinom obrazovanja učitelja, veličinom škole i ustrojstvom matične ili područne škole. Time je djelomično potvrđena druga hipoteza u odnosu na dvije dimenzije znanja 
s općim znanjem o ADHD-u te simptoma s radnim mjestom učitelja razredne nastave i tretmana s nižom kronološkom dobi.

Nalazi ovog istraživanja ukazuju da učitelji ne posjeduju optimalna znanja o ADHD-u i nedovoljno poznaju etiologiju ADHD-a, dok su više upoznati sa simptomima i utjecaju tretmana na uspješnije funkcioniranje učenika s ADHD-om, što je sukladno ranijim studijama (npr. Al-Hakeem et al., 2013; Ghanizadeh et al., 2006; Snider et al., 2003). Učiteljsko poznavanje važnosti uključivanja učenika s ADHD-om u različite programe podrške i psihosocijalnog tretmana ohrabruje, jer je učinkovit tretman jedino moguć uz učinkovitu suradnju obitelji, škole i zdravstvenog sustava (Muanprasart et al., 2014), a učinkovite školske intervencije uz podršku roditelja (Vitanza, 2014). Učiteljska znanja o ADHD-u doprinose učinkovitoj suradnji učitelja sa stručnjacima i roditeljima i primjeni primjerenih intervencija. Učitelji koji su sudjelovali u edukaciji o ADHD-u imaju više znanja o poremećaju i prihvaćaju strategije upravljanja ponašanjem (Vereb i DiPerna, 2004).

S druge strane, sukladno ranijim nalazima (npr. Soroa et al., 2014; Radetić-Paić, 2018), i u ovom je istraživanju utvrđeno da je učiteljsko poznavanje etiologije nedostatno i da učitelji ne znaju da stresni događaji u obiteljskom kontekstu nisu uzročnici ADHD-a. Ovi rezultati ne iznenađuju s obzirom na to da učitelji tijekom inicijalnog obrazovanja stječu tek temeljne spoznaje o osobitostima u učenju i poučavanju svih učenika s teškoćama, među kojima su ovi učenici samo jedna podskupina. Učitelji navode da su im mediji, prijatelji i rodbina glavni izvori znanja o ADHD-u (npr. Al-Hakeem et al., 2013; Ghanizadeh et al., 2006; Snider et al., 2003), što ukazuje da nemaju prilike za stjecanjem ovih znanja tijekom inicijalnog i trajnog profesionalnog razvoja. Kvalitetno obrazovanje za učitelje treba osigurati stjecanje znanja o ADHD-u i razumijevanje da su teškoće u funkcioniranju biološki uvjetovane. Naime, simptomi nepažnje, hiperaktivnosti i impulzivnosti nisu uzrokovani neadekvatnim roditeljskim postupcima ili stresnim obiteljskim uvjetima života, iako oni dodatno ometaju djetetovo funkcioniranje, ali ga ne uzrokuju. Znanja o biološkim uzrocima opisana u uvodu ovoga rada važna su učiteljima u tumačenju ponašanja ovih učenika i primjeni intervencija koje ublažavaju teškoće funkcioniranja. Stoga, treba istaknuti da je učiteljima, povrh kvalitetnog inicijalnog obrazovanja, potrebno osigurati kontinuirana stručna usavršavanja (npr. Topkin et al., 2015) i 
dostupnost stručne podrške i znanja stručnih suradnika, posebice edukacijskih rehabilitatora, kako bi primjerenije interpretirali i reagirali na zahtjevna ponašanja djeteta u usvajanju društvenih normi. Jedino kompetentni učitelji mogu osigurati kvalitetno poučavanje učenika $\mathrm{s}$ ADHD-om i oblikovanje pozitivnog okruženja za učenje (Mohr-Jensen i Steinhausen, 2015).

Većina sociodemografskih obilježja učitelja i obilježja škole nije povezana s procjenom znanja o simptomima, etiologiji i tretmanu ADHD-a, dok je viša razina znanja o simptomima povezana s radnim mjestom učitelja u razrednoj nastavi. Potonji nalaz je očekivan s obzirom na to da učitelji razredne nastave u inicijalnom obrazovanju imaju obvezni kolegij o inkluzivnoj edukaciji, za razliku od predmetnih nastavnika.

Nadalje, u radu se postavila hipoteza da učitelji s više godina radnog staža imaju više znanja o ADHD-u radi većeg iskustva i prilika za stručnim usavršavanjem (npr. Kos et al., 2004). Međutim, rezultati su pokazali obrnuti odnos, ukazujući da učitelji niže kronološke dobi imaju višu razinu znanja o značaju tretmana ADHD-a. Slično, pretpostavka da učitelji zaposleni u većim i matičnim školama imaju dostupniju podršku stručnih suradnika i time dostupnije prilike za stjecanjem znanja o ADHD-u, kao i oni s više godina radnog staža, nije potvrđena u ovom istraživanu. Viša razina znanja učitelja o simptomima i tretmanu ADHD-a statistički je značajno povezana s višom razinom općeg znanja o ADHD-u, a nije povezana sa znanjem o etiologiji ADHD-a, što je u skladu s interkorelacijama među faktorima.

S obzirom na to da godine radnog staža i obilježja škole povezana s dostupnošću stručnog suradnika edukacijskog rehabilitatora, kao što su veličina i ustroj škole kao matične ili područne, nisu relevantni u procjeni znanja učitelja o ADHD-u, može se postaviti pitanje o tome koliko su učiteljima dostupne prilike za stručnim usavršavanjem i podrškom stručnjaka u školi. Drugim riječima, jesu li tijekom svoje profesionalne karijere bili u mogućnosti steći potrebne kompetencije za poučavanje svih učenika, kao i znanja o simptomima, uzrocima i postupcima podrške učenicima s ADHD-om. Također, valja imati na umu da znanje s druge strane utječe na formiranje pozitivnih stavova. Upravo je formiranje primjerenih stavova i reakcija učitelja prema mogućnostima akademskog i socijalnog napredovanja ovih učenika izuzetno značajno tijekom 
poučavanja kako bi učenik mogao ostvariti svoj maksimalni potencijal. Nadalje, znanja utječu i na prepoznavanje simptoma ADHD-a kod učenika, što je prvi korak prema osiguravanju primjerenih oblika školovanja. Naime, učitelji razredne nastave često su prve osobe koje uočavaju da se ponašanje učenika $\mathrm{S} A D H D-o m$ razlikuje od ponašanja tipičnih za određenu dob (Al-Moghamsi et al., 2018). Budući da s učenicima provode svakodnevno od tri do pet sati, učitelji imaju bitnu ulogu u prepoznavanju i regulaciji ponašanja učenika s ADHD-om (Al-Moghamsi et al., 2018). Također, oni imaju i jedinstvenu ulogu u opisivanju ponašanja i funkcioniranja učenika u nastavnim i školskim aktivnostima, što je važan i neizostavan dio procjene u dijagnostičkom postupku za učenike s ADHD-om (Vlah et al., 2018). Znanja o ADHD-u će zasigurno utjecati na sposobnosti suradnje učitelja u interdisciplinarnim timovima (npr. Sherman et al., 2008), čime se dodatno doprinosi mogućnosti napredovanja učenika u školi.

Zaključno, potrebno je istaknuti da pravo učenika na inkluzivni odgoj i obrazovanje ostvaruju jedino kompetentni učitelji koji uz smjernice stručnjaka (edukacijskih rehabilitatora, logopeda i socijalnih pedagoga) pružaju primjerene postupke podrške. Naime, tijekom maturacije učenika s ADHD-om u školskom okruženju, oblikovanje okruženja za učenje sukladno jedinstvenim potrebama ima nemjerljiv potencijal poticanja razvoja i dobrog funkcioniranja ovih učenika, što je prevencija problema mentalnog zdravlja u adolescenciji i odrasloj dobi.

U ovoj studiji korišten je modificirani mjerni instrument dobrih metrijskih karakteristika za ispitivanje znanja učitelja o učenicima $\mathrm{s}$ ADHD-om. Originalno je ispitivao učiteljska znanja o ADHD-u na dihotomnoj skali (Soroa et al., 2014), a za potrebe ovog istraživanja modificiran je na skali od pet stupnjeva. U daljnjim istraživanjima predlažemo izmijeniti tvrdnje u dimenziji Tretmana kako bi više odražavali spektar intervencija karakterističnih za hrvatski kontekst.

Provedeno istraživanje ima dva ograničenja. Prvo se odnosi na način mjerenja znanja skalom Likertovog tipa od pet stupnjeva koja je utvrdila subjektivnu procjenu vlastitoga znanja. Predlaže se primjena skala znanja za utvrđivanje objektivnog znanja i promjena čestica koje više odražavaju obilježja intervencijskih postupaka u hrvatskom odgojno-obrazovnom kontekstu. Primjerice uključivanje različitih postupaka podrške učeniku i njihovim obiteljima te smjernice učiteljima za pri- 
lagodbu nastavnog procesa od stručnih suradnika u školi i stručnjaka izvan škole. Drugo ograničenje ovog istraživanja je prigodan uzorak učitelja te bi u idućem istraživanju rezultate trebalo provjeriti na reprezentativnom uzorku.

\section{Zaključak}

Budući da u Republici Hrvatskoj nedostaje istraživanja o znanjima učitelja o simptomima, etiologiji i tretmanu ADHD-a, ova studija daje nam važne inicijalne spoznaje o ovoj problematici. Sukladno postavljenim ciljevima dobiveni rezultati odgovorili su na dva temeljna pitanja: (1) Koliko učitelji procjenjuju da poznaju simptome, etiologiju i tretman ADHD-a? i (2) U kojoj je mjeri procjena njihova znanja o simptomima, etiologiji i tretmanu ADHD-a povezana sa sociodemografskim obilježjima učitelja, obilježjima škole i njegovoj procjeni općeg znanja o ADHD-a?

Sukladno ranijim istraživanjima utvrđena je viša razina znanja učitelja o simptomima i tretmanu i niža o etiologiji ADHD-a. Učitelji poznaju simptome i značaj tretmana za akademsko i socijalno napredovanje, ali iskazuju nepoznavanje stvarnih etioloških čimbenika ADHD-a i imaju zablude oko obiteljskih i drugih okolnosti življenja kao uzročnika poremećaja. Učiteljsko poznavanje simptoma, etiologije i tretmana ADHD-a nije povezano s godinama radnog staža, veličinom škole i ustrojstvom škole kao matičnom ili područnom školom, što otvara prostor za daljnja istraživanja. Mlađi učitelji su bolje upoznati s mogućnostima tretmana učenika s ADHD-om, a učitelji razredne nastave bolje poznaju simptomatologiju u usporedbi s učiteljima predmetne nastave. Učitelji koji daju opću višu procjenu svog znanja o ADHD-u imaju višu razinu procjene znanja o simptomima i tretmanu, dok nije utvrđena povezanosti s etiologijom. Poznavanje etioloških čimbenika ADHD-a iznimno je značajno za pravilno razumijevanje ponašanja djeteta, što je prema dobivenim nalazima osnovno ograničenje učitelja u poznavanju ovog neurorazvojnog poremećaja.

Stoga, implikacije ovog istraživanja idu u smjeru isticanja značaja kvalitetnog inicijalnog obrazovanja i trajnog profesionalnoga razvoja učitelja u stjecanju znanja o obilježjima/simptomima, etiologiji i tretmanu ADHD-a. Naime, kompetentnost učitelja je jedini način na koji 
se ovim učenicima može osigurati pravo na primjereno školovanje i individualizirane postupke podrške. Obrazovanje učitelja treba uključivati stjecanje recentnih i za nastavnu praksu relevantnih znanja o simptomima, etiologiji i intervencijama te tretmanu ADHD-a: (1) u formalnom inicijalnom obrazovanju, (2) tijekom kontinuiranog formalnog i neformalnog profesionalnog razvoja, i (3) od strane stručnih suradnika edukacijskih rehabilitatora. Profesionalni razvoj učitelja trebao bi im osigurati prilike za formiranje pozitivnih stavova prema mogućnostima ovih učenika i razvoj vještina poučavanja prema individualnim potrebama svakog pojedinog učenika kako bi ostvario svoj maksimalni potencijal. Budući da poremećaj pažnje i hiperaktivnost (ADHD) ima značajan utjecaj na djetetovo akademsko i socijalno funkcioniranje, nužno je temeljito poznavati obilježja ove neurorazvojne teškoće, njenu biološku uvjetovanost i potencijal intervencija usmjerenih na regulaciju ponašanja. Inkluzivan pristup podrazumijeva dostupnost primjernih postupaka podrške učeniku u školskom okruženju od strane kompetentnog učitelja s pozitivnim i realnim stavovima o mogućnostima učenika s ADHD-om.

\section{Literatura}

Abed, Mohaned; Pearson, Susan; Clarke, Paula i Chambers, Mary (2014), „Saudi Arabian teachers' knowledge and beliefs about ADHD «, Journal of the International Association of Special Education, 15(1), str. 67-74.

Al-Hakeem, Hala A. Malik; Al-Othman, Saba'a Naji; Al-Jamea, Latifa Mohamed; Radhi, Ghaida Abdulla; Bu-Ali, Shaikha A. Rahman i Al-Nasir, Faisal (2013), »Knowledge and behavior of primary school teachers towards attention deficit hyperactivity disorder«, Bahrain Medical Bulletin, 35 (3), str. 136-138. https://doi.org/10.12816/0000753

Alkahtani, Keetam (2013), »Teachers' knowledge and misconceptions of attention deficit/hyperactivity disorder«, Psychology, 4(12), str. 963-969. https://doi. org/10.4236/psych.2013.412139

Al-Moghamsi, Esra'a Yahya i Abdulaziz Aljohani (2018), »Elementary school teachers' knowledge of attention deficit/hyperactivity disorder«, Journal of Family Medicine and Primary Care, 7(5), str. 907-915. 10.4103/jfmpc. jfmpc_183_18

American Psychiatric Association (2013), Diagnostic and Statistical Manual of Mental Disorders. https://doi.org/10.1176/appi.books.9780890425596 
Atkinson, Ivan i Shute, Rosalyn (1999), »Managing ADHD: Issues in developing multidisciplinary guidelines «, Australian Journal of Guidance and Counselling, 9(2), str. 119-28. https://doi.org/10.1017/S1037291100003976

Azazy, Samar; Nour-Eldein, Hebatallah; Salama, Hend i Ismail, Mosleh (2018), »Quality of life and family function of parents of children with attention deficit hyperactivity disorder«, Mediterranean Health Journal, 24(6), str. 579587. doi: https://doi.org/10.26719/2018.24.6.579

Barkley, Russell Alan (1997), »Behavioral inhibition, sustained attention, and executive functions: Constructing a unifying theory of ADHD«, Psychological Bulletin, 121, str. 65-94. https://doi.org/10.1037/0033-2909.121.1.65

Barkley, Russell Alan (2006), Attention Deficit Hyperactivity Disorder: A Handbook for Diagnosis and Treatment (3rd ed.), New York: Guilford Press.

Barkley, Russell Alan (2015), »Emotional dysregulation is a core component of ADHD«, u: Barkley, Russell Alan (ur.), Attention-Deficit Hyperactivity Disorder: A Handbook for Diagnosis and Treatment, New York: Guilford Press, str. 81-115.

Blotnicky-Gallant, Pamela; Martin, Cheron; McGonnell, Melissa i Corkum, Penny (2014), »Nova Scotia teachers' ADHD knowledge, beliefs, and classroom management practices« Canadian Journal of School Psychology, 30(1), str. 3-21. https://doi.org/10.1177/0829573514542225.

Brook, Uzi; Watemberg, Nathan i Geva, Diklah (2000), „Attitude and knowledge of attention deficit hyperactivity disorder and learning disability among high school teachers«, Patient Education \& Counseling, 40(3), str. 247-252. https://doi.org/10.1016/S0738-3991(99)00080-4

Faraone, Stephen Vincent; Biederman, Joseph; Mennin, Douglas i Russell, Ronald (1998), »Bipolar and antisocial disorders among relatives of ADHD children: Parsing familial subtypes of illness «, American Journal of Medical Genetics, 81(1), str. 108-116. https://doi.org/10.1002/(SICI)1096-8628(19980207)81:1<108::AID-AJMG18>3.0.CO;2-N

Felt, Barbara T.; Biermann, Bernard; Christner, Jennifer G.; Kochhar, Param i Van Harrison, Richard (2014), »Diagnosis and management of ADHD in children«, American Family Physician, 90(7), str. 456-464.

Ghanizadeh, Ahmad; Bahredar, Mohammad Jafar i Moeini, Seyed Reza (2006), »Knowledge and attitudes towards attention deficit hyperactivity disorder among elementary school teachers«, Patient Education and Counseling, 63(1-2), str. 84-88. https://doi.org/10.1177/2158244014566761

Jurin, Maja i Sekušak-Galešev, Snježana (2008), »Poremećaj pozornosti s hiperaktivnošću (ADHD)-multimodalni pristup«, Paediatria Croatica, 52(3), str. 195-201.

Kehonjić, Selma (2016), Mišljenja učitelja o učenicima s deficitom pažnje/hiperaktivnim poremećajem (ADHD), diplomski rad, Rijeka: Učiteljski fakultet Sveučilišta u Rijeci.

Kos, Julie M.; Richdale, Amanda L. i Hay, David A. (2006), »Children with attention deficit disorder and their teachers: A review of the literature $\ll$, Inter- 
national Journal of Disability, Development, and Education, 53(2), str. 147160. https://doi.org/10.1080/10349120600716125

Kos, Julie M.; Richdale, Amanda L. i Jackson, Mervyn S. (2004), »Knowledge about attention deficit hyperactivity disorder: A comparison of in-service and preservice teachers«, Psychology in the Schools, 41(5), str. 517-526. http:// dx.doi.org/10.1002/pits. 10178

Mohr-Jensen, Christina i Steinhausen, Hans-Christoph (2015), »Time trends in incidence rates of diagnosed attention-deficit/hyperactivity disorder across 16 years in a nationwide Danish registry study «, The Journal of Clinical Psychiatry, 76(3), str. 334-341. https://doi.org/10.4088/JCP.14m09094

Muanprasart, Pongchanok; Traivaree, Chanchai; Arunyanart Wirongrong i Teeranate, Chakriya (2014), »Knowledge of attention deficit hyperactivity disorder and its associated factors among teachers in 3 large primary schools in Phra Nakorn Sri Ayutthaya Province, Thailand«, Journal of the Medical Association of Thailand $=$ Chotmaihet thangphaet, 97, Suppl 2, str. 107-114.

Opić, Siniša i Kudek Mirošević, Jasna (2011), »Handling students with ADHD syndrome in regular elementary schools«, Napredak, 152(1), str. 75-92.

Rader, Robert; McCauley, Larry i Callen, Eric C. (2009), »Current strategies in the diagnosis and treatment of childhood attention-deficit/hyperactivity disorder«, American Family Physician, 79(8), str. 657-665.

Radetić-Paić, Mirjana (2018), »Samoprocjene znanja učitelja o učenicima s deficitom pozornosti / hiperaktivnim poremećajem s obzirom na godine radnoga iskustva«, Školski vjesnik, 67(2), str. 239-250.

Reynolds, Cecil R. i Kamphaus, Randy W. (ur.) (2003), Handbook of Psychological and Educational Assessment of Children: Intelligence, Aptitude, and Achievement, New York: The Guilford Press.

Rowland, Andrew S.; Skipper, Betty J.; Umbach, David M., Rabiner, David L.; Campbell, Richard A.; Naftel, Albert J. i Sandler, Dale P. (2015), »The prevalence of ADHD in a population-based sample«, Journal of Attention Disorders, 19(9), str. 741-754. https://doi.org/10.1177/1087054713513799

Russell, Abigail Emma; Moore, Darren A. i Ford, Tamsin (2016), »Educational practitioners' beliefs and conceptualisation about the cause of ADHD: A qualitative study«, Emotional and Behavioural Difficulties, 21(1), str. 101-118. https://doi.org/10.1080/13632752.2016.1139297

Sekušak-Galešev, Snježana; Frey Škrinjar, Jasmina i Masnjak, Lea (2015), Ispitivanje socijalne uključenosti $i$ kvalitete podrške u sustavima predškolskog, osnovnoškolskog i srednjoškolskog obrazovanja za djecu $i$ učenike $s$ poremećajem iz autističnog spektra (PAS) i deficitom pažnje i hiperaktivnim poremećajem $(A D H D)$, izvješće o istraživanju, Zagreb: Edukacijsko-rehabilitacijski fakultet Sveučilišta u Zagrebu.

Sherman, Jody; Rasmussen, Carmen i Baydala, Lola (2008), »The impact of teacher factors on achievement and behavioural outcomes of children with Attention Deficit/Hyperactivity Disorder (ADHD): A review 
of the literature«, Educational Research, 50(4), str. 347-360. https://doi. org/10.1080/00131880802499803

Snider, Vickie E.; Busch, Tracey i Arrowood, Linda (2003), »Teacher knowledge of stimulant medication and ADHD«, Remedial and Special Education, 24(1), str. 47-57. https://doi.org/10.1177/074193250302400105

Soroa, Marian; Balluerka, Nekane i Gorostiaga, Arantxa (2014), »Development and validation of a questionnaire (the IRA-AGHN) to assess teachers' knowledge of attention deficit hyperactivity disorder«, Anales de Psicologia, 30(3), str. 1035-1043. https://doi.org/10.6018/analesps.30.3.168271

Topkin, Beryl; Roman, Nicolette Vanessa i Mwaba, Kelvin (2015), »Attention deficit disorder (ADHD): Primary school teachers' knowledge of symptoms, treatment and managing classroom behaviour«, South African Journal of Education, 35(2), str. 1-8. https://doi.org/10.15700/saje.v35n2a988

Vaidya, Chandan J. (2012), »Neurodevelopmental abnormalities in ADHD«, Current Topics in Behavioral Neurosciences, 2012(9), str. 49 - 66. https://doi. org/10.1007/7854_2011_138

Vereb, Rebecca L. i DiPerna, James C. (2004), »Teachers' knowledge of ADHD, treatments for ADHD, and treatment acceptability: An initial investigation «, School Psychology Review, 33, str. 421-428. https://doi.org/10.1080/027960 15.2004.12086259

Vitanza, Betti Stanco (2014), Attention-Deficit Hyperactivity Disorder: Teachers' Perceptions and Acceptability of Interventions, PCOM Psychology Dissertations, Paper 315, Philadelphia College of Osteopathic Medicine, Department of Psychology.

Vlah, Nataša; Sekušak-Galešev, Sanja i Skočić Mihić, Sanja (2018), »Relations between teacher and student characteristics in the assessment of symptoms of inattention, impulsivity and hyperactivity related to ADHD «, Socijalna psihijatrija, 46 (4), str. 372-389, https://doi.org/10.24869/spsih.2018.372

Wolraich, Mark L.; Lambert, E. Warren; Baumgaertel, Anna; Garcia-Tornel, Santiago; Feurer, Irene D.; Bickman, Leonard i Doffing, Melissa A. (2003), »Teachers' screening for attention deficit/hyperactivity disorder: Comparing multinational samples on teacher ratings of ADHD«, Journal of Abnormal Child Psychology, 31(4), str. 445-455. https://doi.org/10.1023/A:1023847719796 


\title{
TEACHERS' ASSESSMENT OF KNOWLEDGE ABOUT THE SYMPTOMS, ETIOLOGY AND TREATMENT OF ADHD
}

\author{
Sanja Skočić Mihić, Snježana Sekušak Galešev, Selma Kehonjić
}

The aim of this study was to determine (1) the teachers'level of their perceived knowledge about ADHD and (2) the connection between the teachers' perceived knowledge and their sociodemographic characteristics, characteristics of the school they are affiliated with and their self-assessment of their general knowledge about ADHD. The sample was convenient and included 233 teachers. We used the Questionnaire of Teachers' Knowledge of ADHD with three factored structure: Symptoms, Etiology of ADHD and Treatment of ADHD, with the adequate internal consistency. Teachers are aware of the importance of the treatment for the academic and social outcomes of students with ADHD. They also recognize the symptoms of ADHD. Their knowledge of the etiology of ADHD is insufficient. There are misconceptions related to identifying the cause of ADHD in family stressful circumstances. The teachers' assessment of their general knowledge of ADHD is connected to higher level of knowledge about the symptoms and treatment, and position of primary school teacher. Higher level of knowledge about the treatment is connected to lower age of the teachers. Implications of these findings point out to the importance of obtaining the relevant competences during the initial study of the teachers as well as during their further professional development. The importance of professional support provided by educational rehabilitators is also highlighted.

Keywords: knowledge, teachers, ADHD, symptoms, etiology, treatment 